\title{
RRP15-Like Protein
}

National Cancer Institute

\section{Source}

National Cancer Institute. RRP15-Like Protein. NCI Thesaurus. Code C114396.

RRP15-like protein (282 aa, $\sim 31 \mathrm{kDa}$ ) is encoded by the human RRP15 gene. This protein is involved in ribosomal RNA maturation. 